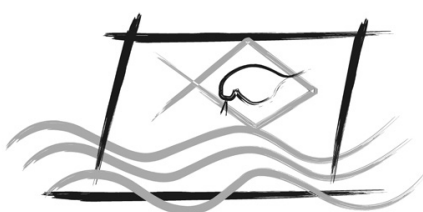

ECOTOX - BRASIL

\title{
Environmental matrices effect in butyltin determinations by GC/MS
}

\author{
Í.B. Castro ${ }^{1,2^{*}}$; P.G. Costa ${ }^{2}$; E.G. Primel ${ }^{3} \&$ G. Fillmann ${ }^{2}$ \\ ${ }^{1}$ Universidade Federal de São Paulo, Instituto de Ciências do Mar. Santos - SP - Brazil, 11030-400 \\ ${ }^{2}$ Universidade Federal do Rio Grande, Instituto de Oceanografia, Laboratório de Microcontaminantes \\ Orgânicos e Ecotoxicologia Aquática (CONECO). Rio Grande - RS - Brazil, 96203-900 \\ ${ }^{3}$ Universidade Federal do Rio Grande, Escola de Química e Alimentos. \\ Rio Grande - RS - Brazil, 96203-900
}

(Received May 18, 2015; Accept August 04, 2015)

\begin{abstract}
The present study evaluated the matrix effect associated to determination of butyltin compounds (tripropyltin (TPrT), tributyltin (TBT), dibutyltin (DBT) and monobutyltin (MBT)) in sediment and mussel tissues using derivatization by Grignard reaction and quantification by gas chromatography coupled mass spectrometry (GC-MS). A non-negligible matrix effect was verified for sediments $(54.2,20.3,13.6$ and $-53.6 \%)$ and mussel tissues $(-12.5,-32.0,59.4$ and $65.7 \%)$ for TPrT, TBT, DBT and MBT respectively. However, this matrix effect was prevailed by preparing the analytical curves using standard addition techniques. Thus, an analytical method was optimized and validated for a more accurate and precise determination of butyltin compounds in sediment and mussel tissue samples.
\end{abstract}

Keywords: Validation; Butyltin; Sediment; Biota; Matrix effect

\section{INTRODUCTION}

Butyltin compounds (OTs), particularly tributyltin (TBT), were used as fluid in transformers and capacitors since 1920s, but its biocides properties were discovered by International Council of Researches on Paints only in 1950s. Thereafter began to be used commercially as fungicides, acaricids and other kinds of pesticides. However, the most well-known OTs application was as active agent in antifouling paints during the last four decades (Almeida et al., 2004, Yebra et al., 2004). Antifouling paints are used in solid surfaces exposed directly to seawater including, hulls of ships, aquaculture nets, off shore structures, and ducts, in order to avoid undesirable incrustation of marine organisms (Champ, 2000, Kotrikla, 2009).

The first TBT antifouling paints (used from 1970s) were soluble matrix type, which provided a very fast initial biocide liberation. However, this system use to lose its efficiency within approximately 12-15 months (Almeida et al., 2007).
Later, TBT was used in self-polishing-paints, compatible with steel and aluminum hulls. These paints were based on acrylic copolymer with TBT groups bonded to the main polymer chain by ester bonds (Godoi et al., 2003). Due to the low polymer solubility in sea water, the paint dissolution could be controlled at molecular level with constant release rates of about $4 \mu \mathrm{g} \mathrm{cm}^{-2}$ per day, which keep the paint effective for up to 7 years (Swennen et al., 1997). As a result, in 1999 almost $70 \%$ of all commercial shipping were using TBT-based selfpolishing-paints, achieving direct savings of approximately US\$2,400 million a year in fuel and other costs (Clark et al., 1988; Almeida et al., 2007). Thus, approximately 50,000 tons of organotin compounds were produced per year between 1990 and 2003 (Godoi et al., 2003).

Due to the intensive use and high toxicity, several enviromental deleteriuos effects have been reported since 1980s in harbors, marinas and shipyards areas contaminated by TBT (Yebra et al., 2004). The most commonly reported effects are 
oysters malformation (Alzieu, 2000), immunosuppression in dolphins (Yang et al., 2006), immuntoxicity in fish (Nakayama et al., 2009), imposex (Lima et al., 2006), and decline of gastropod populations (Castro et al., 2012). Hence, in the early 1980s many countries adopted restritive regulations to the use these marine coatings on ships. In 2001, a global ban against TBT based antifouling paints was proposed by International Maritime Organization (IMO) through the International Convention on the Control of Harmful Antifouling Systems on Ships (AFS convention). According to AFS convention, new applications of these products were banned since $1^{\text {st }}$ January 2003 and its presence on ship surfaces as from $1^{\text {st }}$ January 2008 (IMO, 2014). However, TBT-based antifouling paints are still being widely used in several developing countries, which makes its monitoring still relevant (Bigatti et al., 2009; Paz-Villarraga et al., 2015).

In aquatic environments, TBT is degraded by dealkylation in progressively less toxic dibutyltin (DBT) and monobutyltin (MBT). This cleavage of the tin-carbon bonds may occur photolytically by UV light, microbiologically by fungi or bacteria, or by chemical attack (Gadd, 2000). In order to appraise temporal environmental contamination and trends, DBT and MBT are also determined in addition to TBT (Díez and Bayona, 2009), requiring accurate and selective analytical methods. Currently, despite the derivatization requirement, Gas Chromatography (GC) coupled to flame photometric detector (FPD) (Oliveira et al., 2010), pulsed flame photometric detector (PFPD) (Fernandez et al., 2005) or mass spectrometer detector (MS) (Thomaidis et al., 2007) is most often used to analyze butyltin compounds (BTs) in environmental matrices.

Previous studies related TBT analyses in environmental samples have reported matrix effect (Pereiro et al., 1996; Cardellicchio et al., 2001; Gallego-Gallegos et al., 2006; Tang and Wang, 2007). This problem was first described by Kebarle and Tang (1993) and frequently occur with environmental matrices such as seawater, sediment and biota and might bias, either by increasing or suppressing the analytical signal, the results (Gallego-Gallegos et al., 2006). Standard addition method (Cardellicchio et al., 2001), use of smaller sample mass (Tang and Wang, 2007), use of appropriate internal standards (Van Eeckhaut et al., 2009) and specific clean-up methods (Gallego-Gallegos et al., 2006) have been proposed to reduce or avoid the matrix effect on pesticide analyses. Thus, as many research groups and environment agencies have analyzed BTs in environmental matrices to either investigate the effectiveness of international (IMO) or national restrictions on TBT use or simply appraise the environmental levels, the present study evaluated the matrix effect on the determination of BTs (TBT, DBT, MBT and TPrT) (Figure 1) in environmental samples (sediments and mussel tissues) by GC-MS and Grignard derivatization. Despite being the most widely used method to access TBT environmental contamination, no studies have appraised this bias factor properly yet. A method to reduce the matrix effect and some modifications in the sample preparation proposed by Morabito et al., (1995) were presented.
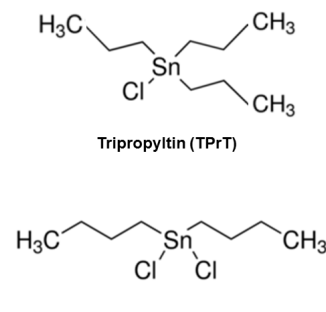

Dibutyltin (DBT)

Figure 1: Molecular structures of tripropyltin (TPrT), tributyltin (TBT), dibutyltin (DBT) and monobutyltin (MBT).

\section{MATERIAL AND METHODS}

\section{Chemicals}

Tributyltin chloride (TBT, 98.2\%), dibutyltin dichloride (DBT, 96.0\%), monobutyltin trichloride (MBT, 95.0\%), tropolone $(98.0 \%)$ and phenylmagnesium bromide in dietylether solution 2M (Grignard reagent) were purchased from Sigma-Aldrich (Bellefonte, PA, USA). Tipropyltin choride (TPrT, 98.9\%, used as surrogate standard), tetrabutyltin (TeBT, 98.8\%, used as internal standard), chloridric acid P.A. and $\mathrm{NaCl}$ were obtained from Merck (Darmstad, Germany). All butyltins concentrations are reported as $\mathrm{Sn}$ (ng Sn $\mathrm{mL}^{-1}$ for solutions or $\mathrm{ng} \mathrm{Sn}^{-1}$ for sediments and mussel tissue). The individual organotin stock standard solutions (1 mg Sn $\mathrm{mL}^{-1}$ ) were prepared in hexane and stored in ambar vials at $4{ }^{\circ} \mathrm{C}$. Working solutions were prepared daily by appropriate concentrations of the stock standard solutions. Hexane, methanol, dichloromethane and toluene of pesticide analysis grade and anhydrous sodium sulphate were purchased from JT Baker (Mexico). Water was purified with a Direct-Q UV3 ${ }^{\circledR}$ (resistivity $18.2 \mathrm{~m} \Omega \mathrm{cm}$ ) water purification system (Millipore, Bedford, MA, USA). All glassware was washed with Extran ${ }^{\circledR}$ solution (Merck, $5 \% \mathrm{v} / \mathrm{v}$ ) and submerged in the same solution for 24 hours. After, the glassware was submerged in nitric acid solution $(5 \% \mathrm{v} / \mathrm{v})$ for 24 hours, washed under flow water and dry at $35^{\circ} \mathrm{C}$. Before the use, all material was rinsed with acetone $(3 x)$ and hexane $(3 x)$ of pesticide analysis grade.

\section{Extraction}

The extraction method for BTs followed Morabito et al., (1995), with modification in the final solvent exchange of isooctane to hexane. Exactly $5 \mathrm{~g}$ of sediments or $1 \mathrm{~g}$ of freeze dried mussel tissues were independently spiked with a mixture of TPrT, MBT, DBT and TBT in appropriate concentrations and left 30 minutes for equilibration. The samples were placed in $40 \mathrm{~mL}$ vials and $15 \mathrm{~mL}$ of tropolone solution 0.05 $\%(\mathrm{w} / \mathrm{v})$ in methanol and $1 \mathrm{~mL}$ of concentrated $\mathrm{HCl}(37 \%)$ were sequentially added. The samples were sonicated for 15 $\min$ (water bath $<40{ }^{\circ} \mathrm{C}$ ), and then centrifuged for $10 \mathrm{~min}$ at $3000 \mathrm{rpm}$. The supernatants were transferred to a $250 \mathrm{~mL}$ separatory funnel filled with $150 \mathrm{~mL}$ of a $10 \% \mathrm{NaCl}$ solution. The extraction procedure was repeated twice. Later, the 
initial extracts were extracted with $20 \mathrm{~mL}$ of dichlorometane $(3 \mathrm{x})$. The collected dichloromethane extract was eluted through anhydrous sodium sulphate and washed with $2 \mathrm{~mL}$ of dichloromethane. After, $5 \mathrm{~mL}$ of hexane were added and the volume reduced to $5 \mathrm{~mL}$ in a rotary evaporator (water bath $<40{ }^{\circ} \mathrm{C}$ and under moderate vacuum). The extracts were transferred to a $40 \mathrm{~mL}$ vials (screw cap with PTFE septa) and evaporated almost to dryness under moderate flow of nitrogen. The volume was then adjusted to $1 \mathrm{~mL}$ (using hexane) for derivatization.

\section{Derivatization}

The transformation of butyltin chlorides into more stable and volatile compounds to allow GC analysis was done by Grignard reaction. That alkylation is the most widely used derivatization technique for organotin determination and was performed by pentylation with pentylmagnesium bromide in dietylether solution (Morabito et al., 2000).

Initially, the $40 \mathrm{~mL}$ vials containing the extract were closed and purged with nitrogen to obtain an inert atmosphere. For that step, it was used needles of stainless steel of $15 \mathrm{~cm}$ connected to the nitrogen line. Later, $2 \mathrm{~mL}$ of pentylmagnesium bromide in diethyl ether solution was injected inside the vials with a glass syringe. The vials were vigorously vortex mixed for 1 minute and allowed to stand for $30 \mathrm{~min}$ with occasional agitation. The excess of Grignard reagent was destroyed by adding $15 \mathrm{~mL}$ of ultrapure water and $1 \mathrm{~mL}$ of $\mathrm{HCl}(37 \%)$, both previously chilled down to $4{ }^{\circ} \mathrm{C}$. That step was done in ice bath to minimize the evaporation losses.

After derivatization, the pentylated butyltins were liquidliquid extracted with $5 \mathrm{~mL}$ of hexane $(3 \mathrm{x})$. Those extracts were evaporated to $0.5 \mathrm{~mL}$ under moderate nitrogen flow $\left(\cong 1 \mathrm{~L} \mathrm{~min}^{-1}\right)$ and transferred to a silica column $(3.5 \mathrm{~g}$ in a glass column $30 \mathrm{~cm}$ length and $15 \mathrm{~mm}$ as internal diameter) previously wet with hexane/toluene mixture (1:1). Hexane/ toluene mixture (1:1) was passed through the column until $15 \mathrm{~mL}$ were collected in a vial. Finally, the extracts were

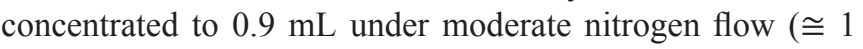
$\mathrm{L} \mathrm{min}^{-1}$ ), $100 \mu \mathrm{L}$ of tetrabutyltin solution (1000 $\mathrm{ng} \mathrm{Sn} \mathrm{mL} \mathrm{L}^{-1}$ ) was added and then injected in the chromatographic system.

\section{Instrument}

All analyses were performed in a gas chromatography Perkin Elmer Clarus 500 coupled with a mass spectrometer and auto sampler. The GC was equipped with a Perkin Elmer column Elite-5MS (30 m x $0.25 \mathrm{~mm}$ I.D., $0.25 \mu \mathrm{m}$ thickness) coated with $5 \%$ diphenyl dimethilpolisiloxane. The carrier gas was high purity helium (99.999 \%) with a constant flow of $1.7 \mathrm{~mL} \mathrm{~min}^{-1}$. The $\mathrm{GC}$ oven temperature was programmed as follows: $2 \mathrm{~min}$ at $80{ }^{\circ} \mathrm{C}$, to $300{ }^{\circ} \mathrm{C}$ at $11{ }^{\circ} \mathrm{C} \mathrm{min}-1$ and constant temperature until final analyses. The injector was kept at $240{ }^{\circ} \mathrm{C}$ in a split mode. The ion source and transfer line temperatures were set at $280^{\circ} \mathrm{C}$. The mass spectrometer was operated in electron ionization mode and electron impact was performed at electron energy of $70 \mathrm{eV}$. The mass spectra obtained at mass-to-change ratio scan range from 150 to 450 $\mathrm{mu}$ and the equipment run in the SIFI mode (simultaneous full scan and selected ion monitoring mode). The dwell time was set to $0.1 \mathrm{~s}$ for each ion. The confirmation was done against the spectra obtained for authentic standards.

\section{Method validation}

The validation process was carried out according to the parameters defined by method validation and quality control procedures for pesticide residues analysis in food and feed of the European Commission (SANCO, 2009), as described below:

\section{Linearity and matrix effect study}

In order to verify the linearity and matrix effect, three analytical curves were constructed for each analyte: in pure solvent, for matrix superposition (using sediments previously decontaminated by thermal treatment $/ 450{ }^{\circ} \mathrm{C}$ for 6 hours) and for standard addition (mussel tissues). The analytical curves concentrations were $2,5,10,25,50,100,250,500$ and 1000 $\mathrm{ng} \mathrm{Sn} \mathrm{mL}^{-1}$. The method linearity was evaluated by the linear regression $(\mathrm{y}=\mathrm{ax}+\mathrm{b})$ and its correlation coefficient $\left(r^{2}\right)$. Afterwards, matrix effects were investigated by comparing the slopes in calibration solutions. The ratio $\mathrm{Sm} / \mathrm{Ss}$ ( $\mathrm{Sm}$ refers to matrix slope and Ss refers to solvent slope) were calculated and the intensity of the effects caused by matrix components was rated according to the \% of signal enhancement or suppression $(\mathrm{C} \%)$, which was calculated as $\% \mathrm{ME}=100 \mathrm{x}$ $(1-\mathrm{Sm} / \mathrm{Ss})$.

\section{Limit of detection (LOD) and quantification (LOQ)}

Limits of detection (LOD) and quantification (LOQ) of the method were calculated for a signal to noise $(\mathrm{S} / \mathrm{N})$ ratio ("peak to peak") obtained by the Turbo Mass software ( $\mathrm{S} / \mathrm{N}=3$ for $\mathrm{LOD}$ and $\mathrm{S} / \mathrm{N}=10$ for $\mathrm{LOQ}$, respectively) using the peak of the lowest concentration. The determination of the LOD was performed by preparing samples with known concentrations of the analyte and by establishing the level at which the analyte could be reliably detected.

\section{Precision and Accuracy}

The precision was evaluated in terms of repeatability $\left(\mathrm{RSD}_{\mathrm{r}}\right)$ and intermediate precision $\left(\mathrm{RSD}_{\mathrm{ip}}\right)$ and was expressed as relative standard deviation (RSD). Treatments with spiked sediment samples in four spiked concentrations $(2,4,20$ and 40

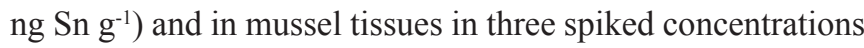

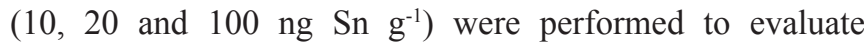
repeatability. The intermediate precision was verified through of experiments intra-day and inter-day accomplished with three fortification levels and different operators, respectively.

The accuracy was evaluated in terms of recoveries from spiked samples and Certified Reference Material (CRM) 
analyses. The analyses were carried out in four concentrations (2, 4, 20 e 40 ng $\left.\mathrm{Sn} \mathrm{g}^{-1}\right)$ of TPrT, TBT, DBT and MBT for sediment samples and three environmental relevant concentrations $\left(10,20\right.$ and $\left.100 \mathrm{ng} \mathrm{Sn} \mathrm{g}^{-1}\right)$ for mussel tissues. For TBT, was also tested the level $1.2 \mathrm{ng} \mathrm{Sn} \mathrm{g}^{-1}$ for sediments

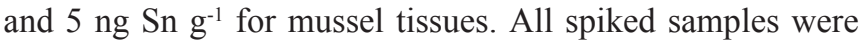
analyzed in triplicate. Additionally the Certified Reference material (PACS-2 / National Research Council of Canada, Ottawa, Canada) was analyzed $(n=5)$. All concentrations were reported as ng Sn $\mathrm{g}^{-1}$ (dry weight).

\section{RESULTS AND DISCUSSION}

The selected chromatography conditions showed a good resolution peak shape (tailing factors and asymmetry $<1.8$ for the studied BTs) for the analytes (Figure 2).

The Table 1 display the retention times $\left(t_{R}\right)$, relative retention times $\left(\mathrm{t}_{\mathrm{RR}}\right)$ and monitored ions. The chromatographic conditions of the validated method provided a similar time of analysis (13.29 minutes) in comparison to other proposed methods for BT determinations (Chou and Lee, 2005). Additionally, the use of a versatile column (Elite-5MS - 30 $\mathrm{m} \times 0.25 \mathrm{~mm}$ I.D., $0.25 \mu \mathrm{m}$ thickness) facilitates the method implementation to BTs analysis in laboratories that have been using GC-MS.

\section{Validation}

\section{Linearity, Matrix Effect(\%ME), and LOD and LOQ}
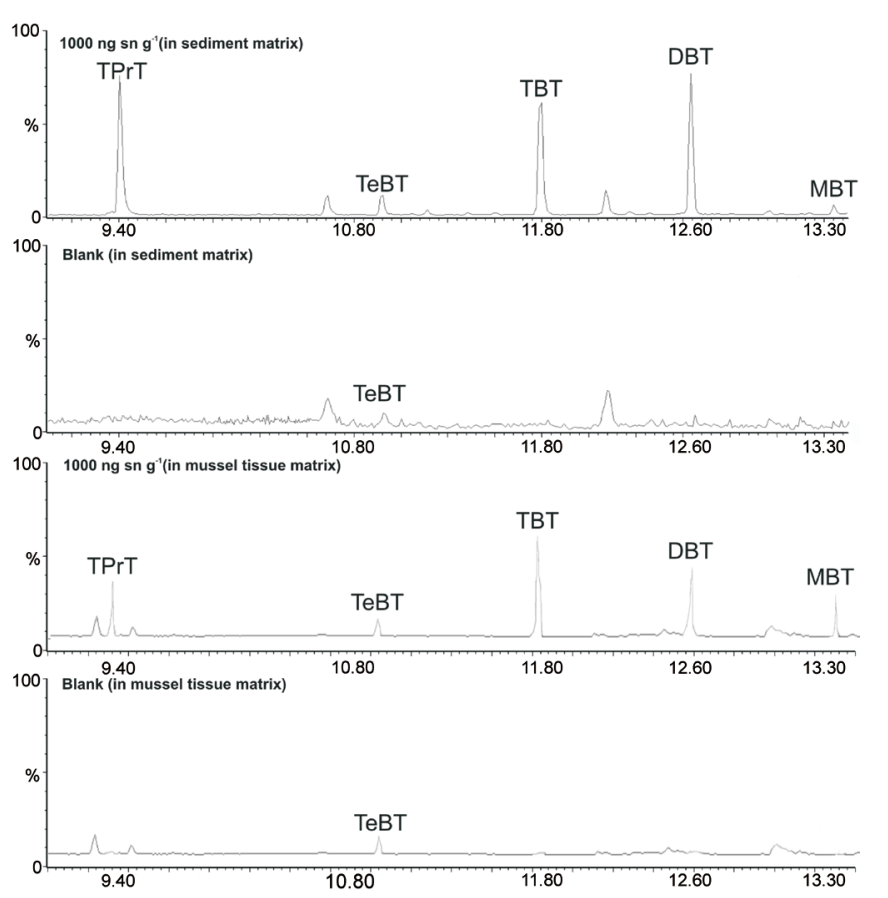

Figure 2: Typical chromatogram of Butyltin compounds in sediments and mussel tissues matrix (spiked and blank). TPrT, TeBT (internal standard), TBT, DBT and MBT. TeBT concentration $=100 \mathrm{ng} \mathrm{Sn} \mathrm{g}^{-1}$, other analites $=$ $1000 \mathrm{ng} \mathrm{Sn} \mathrm{g}^{-1}$.
Table 1: Retention time $\left(\mathrm{t}_{\mathrm{R}}\right)$, relative retention time $\left(\mathrm{t}_{\mathrm{RR}}\right)$ and monitored ion.

\begin{tabular}{lccc}
\hline Compounds & $\begin{array}{c}\mathbf{t}_{\mathrm{R}} \\
(\mathbf{m i n})\end{array}$ & $\begin{array}{c}\mathbf{t}_{\mathrm{RR}} \\
(\mathbf{m i n})\end{array}$ & Monitored Ion \\
\hline TPrT & 9.41 & 0.87 & $207,275,277$ \\
TeBT & 10.88 & - & $177,233,235,291$ \\
TBT & 11.71 & 1.07 & $177,179,305,303$ \\
DBT & 12.53 & 1.16 & $177,249,317,319$ \\
MBT & 13.31 & 1.22 & $193,317,319$ \\
\hline
\end{tabular}

The analytical curve equations, $\% \mathrm{ME}, r^{2}$, LOD and LOQ for TPrT, TBT, DBT and MBT in different tested matrices are summarized in Table 2. The square of regression coefficient $\left(r^{2}\right)$ for the analytical curves of those four studied analytes was always higher than 0.99 for both matrices.

The comparison among the analytical curves equation showed either suppression or enhancement of the BTs signal related to the tested matrices. For sediments, the matrix effect ranged from -53 to 54 considering all analytes. Similarity, mussels tissues presented matrix effect between -12.5 and 65.7. In fact, several authors have reported the higher susceptibility of MS detectors to suffer from matrix effects in comparison to pulsed flame photometric detectors (PFPD) due to the metallic surface and absence of combustion step in the MS detector (Pinho et al., 2009). The matrix effect is caused by the interferents present in the environmental matrices which compete for the ionization with the analytes present in low concentrations. According to Kruve et al. (2008), signal changes higher than $20 \%$ generated by matrix effect are extremely significant and may cause false negative or positive results at lower concentrations. Thus, some precautions such as the use of internal standards and implementation of cleanup methods have been recommended to minimize the matrix effects in pesticide analyses (Gallego-Gallegos et al., 2006; Van Eeckhaut et al., 2009). However, the present results showed that these procedures have not been able to efficiently avoid the matrix effect in BTs analysis by GC-MS. Therefore, it was necessary to apply methods of standard addition and superposition of the matrix for biota and sediments, respectively. This procedure had been used by GallegoGallegos et al., (2006) for ethylated BT determinations in environmental matrices using GC-FPD, but never tested before for determinations of BTs using the derivatization by Grignard reaction and quantification by GC-MS.

In the analytical curve prepared in pure hexane, the LODs were 3.5, 2.5, 5.0 and $3.5 \mathrm{ng} \mathrm{Sn} \mathrm{mL} \mathrm{m}^{-1}$ for TPrT, TBT, DBT and MBT, respectively. However, an improvement in LODs and, consequently, in LOQs, was obtained when the curves were constructed using matrix addition techniques. LODs for curves done into the sediment extracts were 1.5, 0.8, 1.0 and $0.7 \mathrm{ng} \mathrm{Sn} \mathrm{mL} \mathrm{m}^{-1}$ for TPrT, TBT, DBT and MBT, respectively. Similarly, the LOD values for curves prepared using mussel extracts were, respectively, 0.5, 0.7, 0.7 and $0.5 \mathrm{ng} \mathrm{Sn} \mathrm{mL}^{-}$ 1. These results are in accordance with other studies where improvements in the LOD were obtained when the matrix effect was reduced (Iová and Zrostlíková, 2003; Carrasco et al., 2007; Chambers et al., 2007). 
Table 2: Analytical curve equation, matrix effect (\% ME), square of regression coefficient $\left(\mathrm{R}^{2}\right)$, instrumental limits of detection $\left(\mathrm{LOD}_{\mathrm{i}}\right)$, instrumental limits of quantification $\left(\mathrm{LOQ}_{\mathrm{i}}\right)$, sediment method limits of quantification $\left(\mathrm{LOQ}_{\text {sed }}\right)$ and biota method limits of quantification $\left(\mathrm{LOQ}_{\mathrm{bio}}\right)$ for $\mathrm{BTs}$ prepared in pure solvent $_{(\text {sol) }}$, sediment matrix $_{(\text {sed) }}$ and mussel tissues matrix ${ }_{(\text {bio })}$.

\begin{tabular}{lccccccc}
\hline Compound & Analytical curve equation & \% ME & $\mathbf{R}^{2}$ & $\begin{array}{c}\mathbf{L O D}_{\mathrm{i}} \\
\left(\mathrm{ng} \mathrm{Sn} \mathrm{mL}^{-1}\right)\end{array}$ & $\begin{array}{c}\mathbf{L O Q}_{\text {sed }} \mathbf{L O Q}_{\text {bio }} \\
\left(\mathrm{ng} \mathrm{Sn} \mathrm{g}^{-1}\right)\end{array}$ \\
\hline $\mathrm{TPrT}_{\text {sol }}$ & $\mathrm{y}=0.002011660 \mathrm{x}+0.0023393$ & - & 0.9963 & 3.5 & 10 & & \\
$\mathrm{TPrT}_{\text {sed }}$ & $\mathrm{y}=0.000921047 \mathrm{x}-0.0028651$ & 54.2 & 0.9977 & 1.5 & 4.5 & 0.8 & 1.5 \\
$\mathrm{TPrT}_{\text {bio }}$ & $\mathrm{y}=0.002276220 \mathrm{x}-0.0204481$ & -12.5 & 0.9911 & 0.5 & 1.5 & & \\
$\mathrm{TBT}_{\text {sol }}$ & $\mathrm{y}=0.00570193 \mathrm{x}-0.00728584$ & - & 0.9983 & 2.5 & 7.5 & & \\
$\mathrm{TBT}_{\text {sed }}$ & $\mathrm{y}=0.00454291 \mathrm{x}-0.01832051$ & 20.3 & 0.9980 & 0.8 & 2.5 & 0.5 & 2.0 \\
$\mathrm{TBT}_{\text {bio }}$ & $\mathrm{y}=0.00752929 \mathrm{x}-0.03587190$ & -32.0 & 0.9950 & 0.7 & 2.0 & & \\
$\mathrm{DBT}_{\text {sol }}$ & $\mathrm{y}=0.00595851 \mathrm{x}-0.00415379$ & - & 0.9972 & 5.0 & 15 & & \\
$\mathrm{DBT}_{\text {sed }}$ & $\mathrm{y}=0.00514563 \mathrm{x}-0.02247480$ & 13.6 & 0.9960 & 1.0 & 2.0 & 0.5 & 2.0 \\
$\mathrm{DBT}_{\text {bio }}$ & $\mathrm{y}=0.00241850 \mathrm{x}-0.02520004$ & 59.4 & 0.9958 & 0.7 & 2.0 & & \\
$\mathrm{MBT}_{\text {sol }}$ & $\mathrm{y}=0.00091140 \mathrm{x}+0.00083390$ & - & 0.9955 & 3.5 & 10 & & \\
$\mathrm{MBT}_{\text {sed }}$ & $\mathrm{y}=0.00140020 \mathrm{x}+0.00417327$ & -53.6 & 0.9914 & 0.7 & 2.0 & 0.5 & 1.5 \\
$\mathrm{MBT}_{\text {bio }}$ & $\mathrm{y}=0.00031220 \mathrm{x}+0.00242932$ & 65.7 & 0.9945 & 0.5 & 1.5 & & \\
\hline
\end{tabular}

Simply procedures of sample dilution and small sample injection are often used in pesticide analyses to reduce the amount of interference molecules injected into the chromatographic systems and, consequently, minimize the matrix effect (Hernando et al., 2007). However, the use of these techniques hampers the application of pre-concentration procedures, which are often necessary to quantify BTs in environmental levels. Considering the mass of sample used ( $5 \mathrm{~g}$ to sediments and $1 \mathrm{~g}$ to mussel tissues), the LOQ values obtained for sediment $\left(0.8,0.5,0.5\right.$ and $0.5 \mathrm{ng} \mathrm{Sn}^{-1}$ for TPrT, TBT, DBT and MBT, respectively) and for biota samples (1.5,

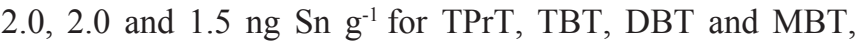
respectively) were consistent with environmental relevant concentrations (Castro et al., 2012).

\section{Precision and Accuracy}

For sediments, the recovery values for all analyzed compounds and spiked levels varied from 92.7 to $117.1 \%$, and the $\mathrm{RSD}_{\mathrm{r}}$ values ranged from 1.1 to $16.4 \%$. In terms of intermediate precision, the recoveries varied between 78.5 and $110.0 \%$ with $\mathrm{RSD}_{\text {ip }}$ ranging between 3.0 and 18.3 (Table 3). Similarly, these values ranged from 72.0 to $118.2 \%$ with RSD $_{\mathrm{r}}$ between 0.8 and $12.2 \%$ for mussels. The recoveries for the intermediate precision varied between 78.3 and $119.4 \%$ with $\mathrm{RSD}_{\text {ip }}$ from 0.7 to $11.4 \%$ (Table 4). These values are within the acceptable limits established for the method validation and quality control procedures for pesticide residues analysis in food and feed of the European Commission (SANCO, 2009).

The Certified Reference Material (for sediments) (PACS-2 $/ n=5)$ presented levels of TBT $\left(871 \pm 36 \mathrm{ng} \mathrm{Sn} \mathrm{g}^{-1}\right)$ and, DBT $\left(1012 \pm 22 \mathrm{ng} \mathrm{Sn} \mathrm{g}^{-1}\right)$ in good agreement with the certified concentrations for TBT $\left(890 \pm 105 \mathrm{ng} \mathrm{Sn} \mathrm{g}^{-1}\right)$ and DBT (1047 \pm $\left.64 \mathrm{ng} \mathrm{Sn} \mathrm{g}^{-1}\right)$. However, MBT (713 $\left.\pm 42 \mathrm{ng} \mathrm{Sn} \mathrm{g}^{-1}\right)$ levels were

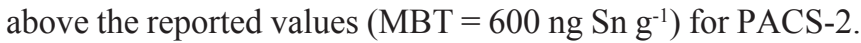
It is possible that the method of superposition of the matrix was not efficient to completely avoid the matrix interferents in the MBT analyses. In addition, the MBT values in PACS2 are not certified. Similar results indicating worst analytical performance for MBT have been observed by several studies (Montigny et al., 1998, Aguerre et al., 2000, Santos et al., 2013). However, considering the small differences between

Table 3: Recovery, repeatability $\left(\mathrm{RSD}_{\mathrm{r}}\right)$ and intermediate precision $\left(\mathrm{RSD}_{\mathrm{ip}}\right)$ of the method used to analyze TPrT, TBT, DBT and MBT spiked at different levels in sediment extracts $(n=9)$.

\begin{tabular}{lccccc}
\hline Compound & $\begin{array}{c}\text { Spike level } \\
\left(\text { ng Sn g }^{-1}\right)\end{array}$ & $\begin{array}{c}\text { Recovery } \\
(\%)\end{array}$ & $\begin{array}{c}\text { RSD }_{\mathrm{r}} \\
(\%)\end{array}$ & $\begin{array}{c}\text { Recovery }_{\mathrm{pi}} \\
(\%)\end{array}$ & $\begin{array}{c}\mathrm{RSD}_{\mathrm{pi}} \\
(\%)\end{array}$ \\
\hline \multirow{4}{*}{ TPrT } & 2 & 97.7 & 10.8 & 78.5 & 18.3 \\
& 4 & 92.7 & 8.0 & 81.3 & 16.4 \\
& 20 & 106.3 & 16.4 & 89.3 & 14.5 \\
& 40 & 101.2 & 5.8 & 96.6 & 7.9 \\
\hline \multirow{4}{*}{ TBT } & 1.2 & 107.9 & 14.6 & 93.3 & 12.5 \\
& 2 & 104.3 & 6.3 & 97.6 & 11.4 \\
& 4 & 105.4 & 2.0 & 98.5 & 6.3 \\
& 20 & 101.3 & 1.1 & 98.3 & 7.1 \\
& 40 & 100.0 & 2.4 & 99.3 & 4.5 \\
\hline \multirow{4}{*}{ DBT } & 2 & 117.1 & 9.2 & 110.0 & 9.9 \\
& 4 & 97.5 & 7.6 & 88.2 & 8.6 \\
& 20 & 104.2 & 9.2 & 91.3 & 3.0 \\
& 40 & 99.6 & 3.8 & 98.6 & 4.5 \\
\hline \multirow{4}{*}{ MBT } & 2 & 97.2 & 9.1 & 94.5 & 16.3 \\
& 4 & 93.8 & 6.1 & 83.7 & 14.5 \\
& 20 & 95.7 & 6.2 & 90.3 & 9.1 \\
& 40 & 96.5 & 3.6 & 85.6 & 7.7 \\
\hline
\end{tabular}


Table 4: Recovery, repeatability $\left(\mathrm{RSD}_{\mathrm{r}}\right)$ and intermediate precision $\left(\mathrm{RSD}_{\mathrm{ip}}\right)$ of the method used to analyze TPrT, TBT, DBT and MBT spiked at different levels in mussel tissue extracts $(\mathrm{n}=9)$.

\begin{tabular}{lccccc}
\hline Compound & $\begin{array}{c}\text { Spike level } \\
\left(\text { ng Sn g-1) }^{-1}\right)\end{array}$ & $\begin{array}{c}\text { Recovery } \\
(\%)\end{array}$ & $\begin{array}{c}\text { RSD }_{\mathrm{r}} \\
(\%)\end{array}$ & $\begin{array}{c}\text { Recovery }_{\mathrm{pi}} \\
(\%)\end{array}$ & $\begin{array}{c}\mathrm{RSD}_{\mathrm{pi}} \\
(\%)\end{array}$ \\
\hline \multirow{3}{*}{ TPrT } & 10 & 83.0 & 0.8 & 89.5 & 4.7 \\
& 20 & 72.0 & 1.9 & 78.3 & 3.1 \\
& 100 & 94.6 & 12.2 & 92.5 & 2.6 \\
\multirow{3}{*}{ TBT } & 5 & 112.9 & 10.3 & - & - \\
& 10 & 101.1 & 2.1 & 100.7 & 2.5 \\
& 20 & 98.7 & 2.3 & 96.3 & 2.0 \\
& 100 & 101 & 1.6 & 98.2 & 0.7 \\
DBT & 10 & 112.0 & 1.2 & 108.0 & 4.6 \\
& 20 & 88.9 & 1.7 & 101.8 & 8.2 \\
& 100 & 93.2 & 2.5 & 98.4 & 2.1 \\
\hline \multirow{3}{*}{ MBT } & 10 & 118.2 & 4.2 & 119.4 & 10.2 \\
& 20 & 106.1 & 5.9 & 108.3 & 9.4 \\
& 100 & 105.5 & 10.4 & 110.6 & 11.4 \\
\hline
\end{tabular}

CRM and detected levels, the present method using standard addition or matrix-matched techniques was more accurate for MBT quantifying.

\section{CONCLUSIONS}

Results confirmed that matrix effect on the determination of butyltins in sediments and mussel tissues samples by GC-MS and Grignard derivatization is relevant. However, this effect can be easily avoided by preparing the analytical curves using standard addition (mussel) or matrix-matched (sediment) methods. The analytical method proved to be effective for the determination of butyltin compounds in these environmental matrices, which are the most frequently used to access BTs contamination.

\section{ACKNOWLEDGMENTS}

The authors acknowledge $\mathrm{CNPq}$, for the financial support I. B. Castro (PhD grant 141550/2007) and G. Fillmann (PQ 314335/2009-9 and 312341/2013-0).

\section{REFERENCES}

AGUERRE, S., BANCON-MONTIGNY, C., LESPES, G. \& POTINGAUTIER, M. 2000. solid phase microextraction (SPME): a new procedure for the control of butyl-and phenyltin pollution in the environment by GC-FPD. The Analyst 125: 263 - 268. http:// dx.doi.org/10.1039/A908322G

ALMEIDA, A.C., WAGENER, A.D.R., MAIA, C.B. \& MIEKELEY, N. 2004. Speciation of organotin compounds in sediment cores from Guanabara Bay, Rio de Janeiro (Brazil) by gas chromatography-pulsed flame photometric detection. Applied Organometallic Chemistry 18: 694-704. http://dx.doi. org/ 10.1002/aoc.661

ALMEIDA, E., T.C. DIAMANTINO \& SOUSA, O. 2007. Marine paints: The particular case of antifouling paints. Progress in Organic Coatings 59: 2-20. http://dx.doi.org/10.1016/j. porgcoat.2007.01.017

ALZIEU, C. 2000. Environmental impact of TBT: the French experience. Science of the Total Environment 258: 99-102. http://dx.doi.org/10.1016/S0048-9697(00)00510-6

ARAUJO, P. 2009. Key aspects of analytical method validation and linearity evaluation. Journal of Chromatography B 877: 2224 2234. http://dx.doi.org/10.1016/j.jchromb.2008.09.030

BIGATTI, G., PRIMOST, M.A., CLEDÓN, M., AVERBUJ, A., THEOBALD, N., GERWINSK, W., ARNTZ, W., MORRICONI, E. \& PENCHASZADEH, P. 2009. Biomonitoring of TBT contamination and imposex incidence along $4700 \mathrm{~km}$ of Argentinean shoreline (SW Atlantic: From $38 \mathrm{~S}$ to 54S). Marine Pollution Bulletin 58: 695-701. http://dx.doi.org/10.1016/j. marpolbul.2009.01.001

CARDELLICCHIO, N., GIANDOMENICO, S., DECATALDO, A. $\&$ DILEO, A. 2001. Speciation of butyltin compounds in marine sediments with headspace solid phase microextraction and gas chromatography - mass spectrometry. Fresenius' Journal of Analytical Chemistry 369: 510-515. http://dx.doi.org/10.1007/ s002160000680

CARRASCO, L., DÍEZ, S. \& BAYONA, J. 2007. Methylmercury determination in biota by solid-phase microextraction: Matrix effect evaluation. Journal of Chromatography A 1174: 2-6. http://dx.doi.org/10.1016/j.chroma.2007.09.051

CASTRO, I.B., PERINA, F. \& FILLMANN, G. 2012. Organotin contamination in South American coastal areas. Environmental Monitoring and Assessment 184: 1781-1799. http://dx.doi. org/10.1007/s10661-011-2078-7

CHAMBERS, E., WAGROWSKI-DIEHL, D.M., LU, Z. \& MAZZERO, J. 2007. Systematic and comprehensive strategy for reducing matrix effects in LC/MS/MS analyses. Journal of Chromatography B 852: 22-34. http://dx.doi.org/10.1016/j. jchromb.2006.12.030

CHAMP, M.A. 2000. A review of organotin regulatory strategies, pending actions, related costs and benefits. Science of the Total Environment 258: 21-71. http://dx.doi.org/10.1016/S00489697(00)00506-4

CHOU, C.C. \& LEE, M. 2005. Determination of organotin compounds in water by headspace solid phase microextraction with gas chromatography-mass spectrometry. Journal of Chromatography A 1064: 1-8. http://dx.doi.org/10.1016/j.chroma.2004.08.166

CLARK, E.L., STERRIT, R.M. \& LESTER, J. 1988. The Fate of Tributyltin in the Aquatic Environment a Look at the Data. Environmental Science and Technology 22: 600-604. http:// dx.doi.org/10.1021/es00171a001

DÍEZ, S., \& BAYONA, J. 2009. Butyltin occurrence and risk assessment in the sediments of the Iberian Peninsula. Journal of Environmental Management 90: p.S25-S30. http://dx.doi. org/10.1016/j.jenvman.2008.07.021

VAN EECKHAUT, A., LANCKMANS, K., SARRE, S., SMOLDERS, I, \& MICHOTTE, Y. 2009. Validation of bioanalytical LC-MS/MS assays: Evaluation of matrix effects. Journal of Chromatography B 877: 2198-2207. http://dx.doi. org/10.1016/j.jchromb.2009.01.003

FERNANDEZ, M.A., WAGENER, A., LIMAVERDE, A., SCOFIELD,A., PINHEIRO, F. \& RODRIGUES, E. 2005. Imposex and surface sediment speciation: A combined approach to evaluate organotin contamination in Guanabara Bay, Rio de Janeiro, Brazil. Marine Environmental Research 59: 435-452. http://dx.doi.org/10.1016/j.marenvres.2004.07.001

GADD, G.M. 2000. Microbial interactions with tributyltin compounds: detoxification, accumulation, and environmental fate. Science of the Total Environment 258: 119-127. http:// dx.doi.org/10.1016/S0048-9697(00)00512-X

GALlEGO-GALlEGOS, M., LIVA, M., OLIVAS, R.M. \& CAMARA, C. 2006. Focused ultrasound and molecularly 
imprinted polymers: A new approach to organotin analysis in environmental samples. Journal of Chromatography A 1114: 82-88. http://dx.doi.org/10.1016/j.chroma.2006.02.040

GODOI, A.F.L., FAVORETO, R. \& SANTIAGO-SILVA. D.M. 2003. Contaminação Ambiental Por Compostos Organoestânicos. Química Nova 26: 708-716.

HERNANDO, M.D., SUÁREZ-BARCENA, J., BUENO, M.J.M., GARCIA-EYES, J.F. \& FERNANDEZ-ALBA, A. 2007. Fast separation liquid chromatography-tandem mass spectrometry for the confirmation and quantitative analysis of avermectin residues in food. Journal of Chromatography A 1155: 62-73. http:// dx.doi.org/10.1016/j.chroma.2007.02.120

IMO. 2014. Status of multilateral Conventions and instruments in respect of which the International Maritime Organization or its Secretary-General performs depositary or other functions.

IOVÁ, J.H. \& ZROSTLÍKOVÁ, J. 2003. Matrix effects in (ultra) trace analysis of pesticide residues in food and biotic matrices. Journal of Chromatography A 1000: 181-197. http://dx.doi. org/10.1016/S0021-9673(03)00539-9

KEBARLE, P. \& TANG, L. 1993. From ions in solution to ions in the gas phase - the mechanism of electrospray mass spectrometry. Analytical Chemistry 65: 972A-986A. http://dx.doi.org/10.1021/ ac00070a001

KOTRIKLA, A. 2009. Environmental management aspects for TBT antifouling wastes from the shipyards. Journal of Environmental Management 90: S77-S85. http://dx.doi.org/10.1016/j. jenvman.2008.07.017

KRUVE, A., KANNAPAS, A., HERODES, K. \& LEITO, I. 2008. Matrix effects in pesticide multi-residue analysis by liquid chromatography-mass spectrometry. Journal of Chromatography A 1187: 58-66. http://dx.doi.org/10.1016/j.chroma.2008.01.077

LIMA, A. F., CASTRO, I.B. \& ROCHA-BARREIRA, C. 2006. Imposex induction in Stramonita haemastoma floridana (Conrad, 1837) (Mollusca: Gastropoda: Muricidae) submitted to an organotin-contaminated diet. Brazilian Journal of Oceanography 54(1): 85-90. http://dx.doi.org/10.1590/S167987592006000100008

MORABITO, R., CHIAVARINI, S. \& CREMISINI, C. 1995. Speciation of organotin compounds in environmental samples by GC-MS. In P. Quevauviller, E. A. Maier, and B. Griepink [eds.], 435-464. Elsevier Science, Amsterdam, Netherlands. http:// dx.doi.org/10.1016/S0167-9244(06)80018-1

MORABITO, R., MASSANISSO, P. \& QUEVAUVILLER, P. 2000. Derivatization methods for the determination of organotin compounds in environmental samples. TrAC, Trends in Analytical Chemistry 19: 113-119. http://dx.doi.org/10.1016/ S0165-9936(99)00196-X

MONTIGNY, C., LESPES, G. \& POTIN-GAUTIER, M. 1998. Matrix effects and selectivity of the detector in the determination of butyl-and phenyltins by gas chromatography-flame photometric detection. Journal of Chromatography A 819(1): 221-230. http://dx.doi.org/10.1016/S0021-9673(98)00351-3

NAKAYAMA, A., SEGNER, H. \& KAWAI, S. 2009. Immunotoxic effects of organotin compounds in teleost fish. In T. Arai, H.
Harino, M. Ohji, et al. [eds.], 207-218. Springer, Tokyo, Japan. Available at: http://dx.doi.org/10.1007/978-4-431-85709-9_12.

OLIVEIRA, C.R., SANTOS, D.M., SANTOS, L. \& MARCHI, M. 2010. Speciation of butyltin derivatives in surface sediments of three southern Brazilian harbors. Journal of Hazardous Materials 181: 851-856. http://dx.doi.org/10.1016/j.jhazmat.2010.05.091

PAZ-VILLARRAGA, C.A., CASTRO, I.B., MILOSLAVICH, P. \& FILLMANN, G. 2015. Venezuelan Caribbean Sea under the threat of TBT. Chemosphere 119: 704-710. http://dx.doi. org/10.1016/j.chemosphere.2014.07.068

PEREIRO, I.R., SCHMITT, V.O., SZPUNAR, J., DONARD, O. \& LOBINSKI, R. 1996. Speciation Analysis for Organotin Compounds in Biomaterials after Integrated Dissolution, Extraction, and Derivatization in a Focused Microwave Field. Analytical Chemistry 68: 4135-4140. http://dx.doi.org/10.1021/ ac9604797

PINHO, G.P., NEVES, A.A., QUEIROZ, M. \& SILVÉRIO, F. 2009. Efeito de matriz na quantificação de agrotóxicos por cromatografia gasosa. Química Nova 32: 987-995. http://dx.doi. org/10.1590/S0100-40422009000400030

SANCO. 2009. Method validation and quality control procedures for pesticide residues analyses in food and feed. European Commission.

SANTOS, D., MARCHI, M.R., GODOI, A.F., TURRA, A. \& MONTONE, R. 2013. Matrix effect on butyltin analysis of sediments and fish tissues by GC-PFPD. Journal of the Brazilian Chemical Society 24: 998 - 1005. http://dx.doi. org/10.5935/0103-5053.20130129

SWENNEN, C., RUTTANADAKUL, N., ARDSEUNGNERN, S., SINGH, H.R., MESINK, B.P. \& TEN HALLERS-TJABBES, C.C. 1997. Imposex in sublittoral and littoral gastropods from the Gulf of Thailand and strait of Malacca in relation to shipping. Environmental Technology 18: 1245-1254. http://dx.doi. org/10.1080/09593331808616646

TANG, C.H. \& WANG, W.H. 2007. Optimization of an analytical method for determining organotin compounds in fish tissue by base-hydrolysis pretreatment and simultaneous ethylationextraction procedures. Analytica Chimica Acta 581: 370-376. http://dx.doi.org/10.1016/j.aca.2006.08.029

THOMAIDIS, N.S., STASINAKIS, A.S., GATIDOU, G., MORABITO, R., MASSANISSO, P. \& LEKKAS, T.D. 2007. Occurrence of organotin compounds in the aquatic environment of Greece. Water Air and Soil Pollution 181: 201-210. http:// dx.doi.org/10.1007/s11270-006-9293-9

YANG, R., ZHOU, Q., LIU, J. \& JIANG, G. 2006. Butyltins compounds in molluses from Chinese Bohai coastal waters. Food Chemistry 97: 637-643. http://dx.doi.org/10.1016/j. foodchem.2005.03.049

YEBRA, D.M., KIIL, S. \& DAM-JOHANSEN, K. 2004. Antifouling technology: past, present and future steps towards efficient and environmentally friendly antifouling coatings. Progress in Organic Coatings 50: 75-104. http://dx.doi.org/10.1016/j. porgcoat.2003.06.001 